\title{
Analysis of community needs around the Mallawa Resort in Bantimurung Bulusaraung National Park for Conservation of Natural Orchids
}

\author{
St. Fatmah Hiola ${ }^{1}$, Gufran Darma Dirawan ${ }^{2}$ \\ \{fatmah.hiola@unm.ac.id ${ }^{1}$, gufrandarma@yahoo.com ${ }^{2}$ \} \\ Biology Department, Universitas Negeri Makassar ${ }^{1}$, Environmental Education, Universitas Negeri \\ Makassar $^{2}$
}

\begin{abstract}
The purpose of this study was to explore information about community exceptions in the study area for the preservation of natural orchids. This type of research is descriptive using survey methods by conducting interviews and distributing questionnaires to explore information about the needs of the community related to the conservation of natural orchids. The results revealed that basically the community around the Mallawa Resort area was familiar with natural orchid plants $(65.93 \%)$ but knowledge of natural orchids and their preservation was still lacking (38.27). Generally, people have a caring attitude towards the existence of natural orchids $(68.52 \%)$. This can be seen from the orchids that are owned by the community generally comes from nature $(50.62 \%)$ and have been able to develop them (46.91\%). The conclusion illustrates the need for an activity to preserve natural orchids through the development of a training model for the community around the study area.
\end{abstract}

Keywords: Conservation, Mallawa Resort, Natural orchids, Need an analysis of community

\section{Introduction}

In Law of Republic of Indonesia No. 5 of 1990, stated that biodiversity is diversity among living things from all sources, including land, oceans and other aquatic ecosystems, as well as ecological complexes that are part of its diversity, including diversity within species, between species and ecosystems. Indonesia has recorded 25 biodiversity hotspots, one of which is Wallacea. Sulawesi Island is the largest island in Wallacea, known to have a mixture of oriental and Australian fauna, and is where various endemic fauna are found [1]. While for the endemic flora of Sulawesi, its uniqueness and diversity have been recognized, but until now there are still many that have not been revealed. Whitmore (1975) states that Indonesia has 25,000 species of flowering plants, 515 species of mammals, more than 600 species of reptiles, 270 species of amphibians, more than 8,500 species of fish, 1519 species birds and is a country that has a coral reef with the richest species diversity in the world [2]. While in the forestry sector, there are 500 species of Dipterocarpaceae (potential wood plants) and 3000-4000 orchid species [3]. In a recent review of orchids, Thomas and Schuiteman [4], had carried out a preliminary study of orchid inventory in Sulawesi and Maluku, a total of 820 species were recorded where $60 \%$ (548 
species) were found in Sulawesi. Based on the biodiversity data, it is clear that our country has a high potential for biological resources.

One of the conservation areas in South Sulawesi with sufficient potential for in-situ development of natural orchids is the Bantimurung Bulusaraung National Park or commonly called Babul National Park. According to Hiola et.al. [5], that there were 40 types of orchids in the Mallawa Resort area in Babul NP. But since Babul NP has been designated as one of the conservation areas, there have been many pressures with the presence of communities in and around the area. This indirectly affects the sustainability of natural orchids and their habitat. Therefore, it is necessary to conduct research on the analysis of community needs for the conservation of natural orchids.

\section{Research Method}

This research was conducted from June to August 2019 in the area around Mallawa Resort, Bantimurung Bulusaraung National Park, covering three villages namely Barugae Village, Bentenge Village, and Samaenre Village. Mallawa Resort is located about $90 \mathrm{~km}$ east of Makassar City and $60 \mathrm{~km}$ east of Maros City. Precisely at coordinates 119 34'17 "-119 55'13" E; 442'49" $-5^{\circ} 06^{\prime} 42^{\prime \prime} \mathrm{S}$.

This research is a descriptive study, using survey methods. Data collection techniques carried out through in-depth interviews with respondents, questionnaires, and documentation. Giving questionnaire aimed at exploring information about the needs of the community related to the level of knowledge, attitudes, and their concern for the preservation of orchids and their habitats.

The technique of determining respondents in this study uses purposive sampling, with the consideration that respondents are people with a minimum age of 17 years (adults) who have known, owned or maintained orchids. The number of respondents in this context is not determined by the level of representation of the population, but rather the respondents must be representative in providing the information needed in accordance with the focus of the research objectives.

Data collection through interviews, questionnaires, and documentation. Interviews conducted using in-depth interviews, in order to gather information from respondents regarding orchids and their habitat. A questionnaire conducted to gather information related to knowledge, attitudes and public awareness of the preservation of natural orchids and their habitats. Documentation, carried out to collect supporting data related to the conservation of natural orchids. The data analysis is done by tabulating the data that has been obtained.

\section{Results and Discussion}

The results of the study obtained information about the knowledge and attitudes of the community towards the conservation of orchids that they had previously obtained. Based on orchid ownership data it is known that 18 people $(65.93 \%)$ of 27 respondents have been able to recognize natural orchids. Generally, the main work of the people who live around the Mallawa Resort in Bantimurung Bulusaraung National Park (Babul NP) is farmers, so that they are more or less familiar with the technique of cultivating plants, although in farming for different types of food plants they are very different from orchid plants, but the basic knowledge of farming 
they already have. Respondents generally recognize plants called orchids, but only a few people can distinguish natural orchids based on their type. This is consistent with information obtained from interviews that respondents generally know what is called an orchid, but it is only limited to one or two types, such as phalaenopsis orchids called mattuju orchids and orchids that have a fragrant aroma called incense orchids.

Based on local knowledge about natural orchids shows that community knowledge about natural orchids is only around $38.27 \%$ (10 respondents). Some knowledge that has become a benchmark for the community, among others, is the meaning of the preservation of natural orchids, what activities can be carried out in the development of natural orchids, and why conservation of natural orchids is important to do. The low knowledge of the community (respondents) indicates that so far they have not understood the importance of the existence of natural orchids in their habitat, even though such information is very important to be known by the community, especially those living around conservation areas so that the existence of natural orchids in their habitat can remain sustainable.

Data on the attitude of community awareness towards the existence of natural orchids is still relatively good, around $68.52 \%$ (19 respondents). This is in line with information obtained from interviews with respondents that they generally have a desire to develop natural orchids. One of the actions that have been taken through the maintenance of natural orchids that are owned, even with limited knowledge. Based on the survey results it is known that the community likes to maintain orchids, but the treatment given is modest, without accompanied by fertilization and other maintenance due to their lack of knowledge. One thing that makes the natural orchids that are maintained by the community can still grow even though not optimal because the climate in the study area is quite supporting the growth of orchids which are orchids from the forest. Therefore, in preserving natural orchids and their habitat, support from various parties is needed, especially the people around the area.

Based on data on orchid ownership shows that about $50.62 \%$ (14 people) of the total number of respondents claimed to own and maintain orchids, but most of them informed that the orchids owned came from in or around the Babul NP area. Though taking orchids from conservation areas are too late. This is due to the lack of public knowledge about the prohibition rules. This is certainly contrary to government regulations contained in Minister of Forestry Regulation No. P.19/Menhut-II/2004 concerning Collaborative Management of Nature Reserve Areas and Nature Conservation Areas. This means that efforts to optimize the implementation of conservation programs and improve socio-economic conditions of local communities around conservation areas are through collaborative management activities, which involve the community in their management so that the community will feel ownership of and protect the area.

Based on survey data on 27 respondents it is known that there is $46.91 \%$ (13 respondents) have developed orchid plants even though they are carried out independently. This can be seen when the research was conducted, the involvement of other stakeholders (local government) did not yet exist, the only party actively involved and supporting activities were only the NP. Babul. The low level of community involvement in development is closely related to the principle of benefits received by the community.

Based on the survey results, it is known that the benefits of natural orchid development felt by the community amounted to $22.84 \%$ ( 6 respondents). This is because the community has never been given knowledge about the importance of preserving natural orchids, the economic value of the existence of natural orchids, and future opportunities in the development of natural orchids, as well as other benefits. That is why people feel reluctant to be actively involved in the development of natural orchids. They think that the responsibility for sustainability is solely 
the government and local authorities. According to Ristianasari et.al. [6] that efforts to increase understanding of the community and implement empowerment in accordance with the community are important and relevant in realizing independence as an effort to empower.

Based on survey data, it is known that public engagement has so far been low. In addition, the lack of involvement of other stakeholders in the conservation of natural orchids apart officer manager Resort Mallawa Babul NP. Out of the 27 respondents, only about $11.38 \%$ (3 people) have been involved in the preservation of orchids, and even that is because they are family members of resort officials and surrounding neighbors only.

Therefore, community engagement activities and other parties need to be carried out, so that all parties understand the importance of preserving the natural orchid and its habitat, and can contribute.

\section{Conclusion}

Based on the results obtained, it can be concluded that the community around the Mallawa Resort in Babul National Park requires activities that can improve their knowledge, skills, and concern for the preservation of natural orchids and their habitats.

Acknowledgments. This research was conducted using BNPB funds from the Makassar State University Postgraduate. The author would like to thank Prof. Dr. Hamsu Abdul Gani as Director of the Postgraduate Program at Makassar State University which has provided the opportunity to conduct research. The author also expressed his appreciation to Mr. Yusak Mangetan as Head of Babul NP, who gave permission to conduct research in Babul NP. Finally, the authors sincerely thank the exploration team (Nirwana, Suhardani, and Hilmiah).

\section{References}

[1] Coates BJ, Bishop KD, Gardner D. Gardner Field Guide Birds Wallacea Region. Bird Life International-Indonesian Programme \& Dove Publication, Bogor. (2000)

[2] Anonymous. Biodiversity Action Plan for Indonesia. Ministry of National Development Planning/National Development Planning Agency, Jakarta (1993)

[3] Marsono, Marsono. Konservasi Sumberdaya Alam dan Lingkungan. Pengelolaan Kawasan Konservasi. Bigraf Publishing kerja sama dengan Sekolah Tinggi Tehnik Lingkungan "YLH", Jogjakarta

[4] Thomas S, Schuiteman A. Orchids of Sulawesi and Maluku: A preliminary catalogue. Lindleyana 17 (1): 1-72. (2002)

[5] Hiola, S.F., G.D. Dirawan, M. Wiharto, Syamsiah. et.al. Characteristics of Wild Orchids in Mallawa Resort at Bantimurung Bulusaraung National Park, South Sulawesi, Indonesia. IOP Conf. Ser.: Mater. Sci. Eng. 551 012132. (2019)

[6] Ristianasari Ristianasari, Pudji Muljono, Darwis S. Gani. Dampak Program Pemberdayaan Model Desa Konservasi Terhadap Kemandirian Masyarakat: Kasus Di Taman Nasional Bukit Barisan Selatan Lampung. e-Journal Penelitian Sosial dan Ekonomi Kehutanan, Vol. 10, No. 3 (2013) 